\title{
Land Use and Plant Diversity of the Dahliafleur Reserve of Bingerville (South of Côte d'Ivoire)
}

\author{
Konan Akissi Elise ${ }^{1}$, Koffi Kouadio Arsène Dieudonné ${ }^{1}$, \\ Kouassi Konan Edouard ${ }^{1,2}$, Silue Pagadjovongo Adama ${ }^{3}$, \\ Kouakou Abell Mike ${ }^{1}$, Koutouan Mylène ${ }^{1,2}$, \\ Kone Kouhounatchoho Arthur ${ }^{1}$
}

\begin{abstract}
${ }^{1}$ Université Félix Houphouët-Boigny d'Abidjan, Laboratoire " Milieux des Milieux Naturels et Conservation de la Biodiversité », UFR Biosciences

${ }^{2}$ Université Félix Houphouët-Boigny d'Abidjan, Laboratoire " Milieux des Milieux Naturels et Conservation de la Biodiversité », UFR Biosciences. West African Science Service Center on Climate Change and Adapted Land Use/Centre d'Excellence Africain sur le Changement Climatique, la Biodiversité et l'Agriculture Durable (WASCAL/CEA-CCBAB)

${ }^{3}$ Université Péléforo Gon Coulibaly de Korhogo, Département de Biologie Végétale, UFR Sciences Biologiques

Abstract: Bingerville is one of the cities of the District of Abidjan which are experiencing rampant urbanization. Despite this urbanization, the government has managed to preserve an area called the Dahliafleur Reserve as a refuge for biodiversity in this highly urbanized area. The sustainable management of this Reserve inevitably requires knowledge of the different types of land use and flora. The objective of the present study was to determine the ecological role that this Reserve could play. Land cover mapping and botanical inventories were the main methods used. The results obtained revealed a variability of the types of occupation and of the soil with different surface areas. The Reserve is made up of mosaics of secondary forests, fallow land and bamboo groves. The characterization of the flora made it possible to identify 107 species divided into 87 genera and 44 families. The Guinean-Congolese species are the most abundant. Phanerophytes are dominant in the Reserve. The presence of a non-negligible number of species with special status marks an interest in conservation in this anthropized environment. The diversity indices and specific richness are low. These relatively low values confirm the state of degradation of the vegetation already revealed by satellite images in the Reserve.
\end{abstract}

Keywords: Dynamics, Biodiversity, Conservation, Dahliafleur, Côte d'Ivoire

\section{Introduction}

The need to conserve and protect biological diversity on a planetary scale was established in the framework of the Rio Convention, adopted in 1992. Since then, the principle of maintaining biodiversity has occupied a central place in the various conventions and various principles of sustainable development. Biological diversity is however still considered, at least in popular discourse, as an issue reserved for tropical areas, or at least for natural environments far from urban areas (Elander et al., 2005). The role of biodiversity in maintaining facilities and the services it provides to humans have not yet been integrated into collective consciousness. This statement is attested to be truer for humans living in urban areas. However, these environments constitute a complex and dynamic mosaic of biotopes (Pickett and Cadenasso, 2006), offering multiple habitats for many species of animals and plants. At the International Conference on Biodiversity entitled Science and Governance held in Paris in 2005, a shared enlargement issue was the safeguard of natural elements in urban and peri-urban environments. This raised the question of the conservation of urban biodiversity at the heart of sustainable development policies. It follows the need for cities to publish policies to protect urban biodiversity or update policies for the protection of urban green spaces for this purpose.

Cities play a major part in providing services and built facilities, in addressing inequalities and in managing environments that promote human health. For example, urbanization can increase exposure to common risk factors for noncommunicable diseases, such as changes in physical activity and diet. Urbanization is also generally accompanied by an increase in air pollution which causes significant mortality from cardiovascular and respiratory diseases. However, urban forests contribute to the quality of life of communities through the ecological services they provide. And, finally, because urban biodiversity is often the only reservoir of nature with which some residents come into contact (Müller and Werner, 2010). Many cities are already taking action in this direction, in an innovative, enthusiastic and inspiring way. This is the case of the District of Abidjan which has the Banco National Park (PNB)

This article is published under the terms of the Creative Commons Attribution License 4.0 Author(s) retain the copyright of this article. Publication rights with Alkhaer Publications. Published at: http://www.ijsciences.com/pub/issue/2021-06/

DOI: 10.18483/ijSci.2461; Online ISSN: 2305-3925; Print ISSN: 2410-4477 
and the Dahliafleur Reserve in Bingerville. For the latter, it is located in an area that is experiencing a real estate boom leading to the destruction of plant cover in urban areas and its corollaries. The objective of this study is to determine the ecological role of the Dahliafleur Reserve in a highly urbanized area. Specifically, this will involve studying land use, analyzing the flora and evaluating the carbon footprint of this Reserve.

\section{Methodology}

\subsection{Study site}

The Dahliafleur Reserve is located in the municipality of Bingerville in the District of Abidjan in the south of the Côte d'Ivoire (Figure 1). The
Reserve covers an area of 148 hectares. It is limited in its northern part, by the villages "Carrière I and II" and by the Ebrié lagoon in its eastern part (Monssou, 2018). To the south and west, residential areas limit it. The corresponding climate is of the subequatorial type (Edlin et al., 1971). It is characterized by high rainfall and high humidity, daytime temperatures average $25^{\circ} \mathrm{C}$ to $30^{\circ} \mathrm{C}$ annually and abundant rainfall reaches $350 \mathrm{~mm}$ in the month of June (Asseh, 2019). It has two seasons, a rainy and a dry one. The rainy season spans two periods: March to July and September to November. The dry season is also spread over two periods: from December to February and the month of August.

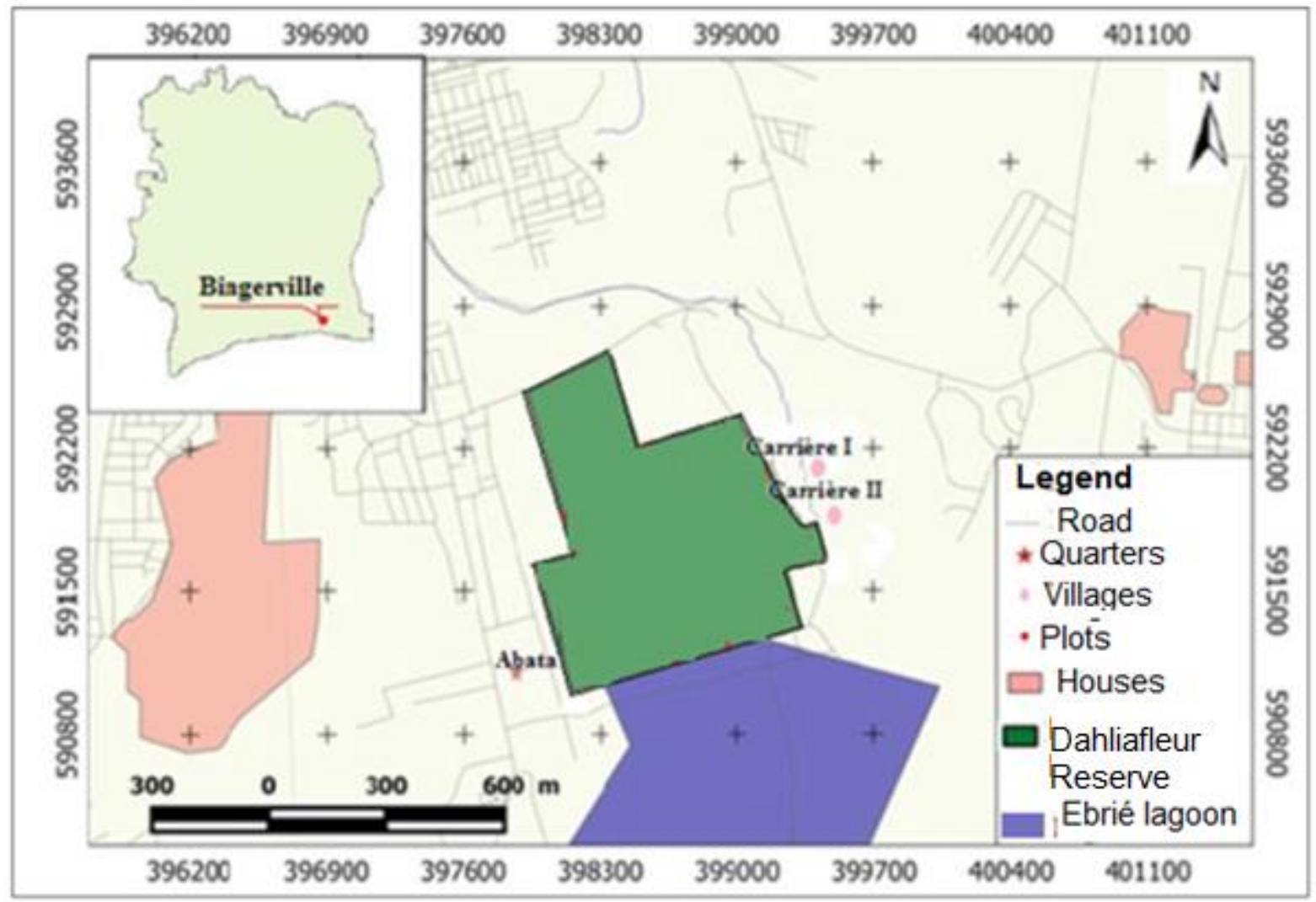

Figure 1: Location of the study area (Monssou et al., 2018)

\subsection{Data collection method}

The data collection was structured around three methods. Remote sensing analysis techniques and the Geographic Information System (GIS) were first used to map the vegetation cover for 2020. Botanical inventories were carried out to characterize the flora in the different types of vegetation land use and estimate the woody biomass of the Dahliafleur Reserve.

\subsubsection{Mapping of current land use}

The production of the maps was made possible thanks to the various data collection missions in the field. The mapping was carried out in three stages: preprocessing of satellite images; extracting information from images; and the field description of the types of occupations identified during the pretreatment.

\subsubsection{Method of botanical inventories of different types of land use}

The botanical inventories were carried out using two complementary methods of floristic surveys: itinerant surveys and surface surveys. The combination of these methods made it possible to identify the maximum number of species present in the types of land cover. 
The surface survey method is commonly used for forest inventories (Adou Yao et al., 2007; Kouassi, 2000; Kouassi, 2007). It consists of listing all the taxa found on areas of varying shapes with the aim of identifying as many species as possible (Kouamé, 2009). In our study, square plots of $25 \mathrm{~m}$ x $25 \mathrm{~m}(625$ $\mathrm{m}^{2}$ ) were installed in the different types of land use. In each type of land use, six (06) plots were installed and arranged at random. Once the plots are delimited, their geographic coordinates are recorded using the GPS receiver. In these plots, the presence of all the species encountered was noted. The circumferences of arborescent individuals with a diameter at human breast height $(\mathrm{DBH})$ greater than or equal to $5 \mathrm{~cm}$ were also measured. Choosing a minimum DBH of 5 $\mathrm{cm}$ maximizes the diversity of plant species. According to Tchouto (2004), Kouamé et al. (2008) and Kouamé (2009), the diversity reflected only by individuals with $\mathrm{DBH} \geq 10 \mathrm{~cm}$, does not reflect more than 50 p.c. of all the diversity of an environment. Also, Vroh (2013) have shown that the diversity of tree species is maximized when DBH is reduced in dense forest.

The method of surface survey was also used. It consisted in traversing the environment by picking up all the plant individuals encountered. This method is suitable for quick inventories, sites that are difficult to penetrate or large surfaces (Vroh, 2013). All species not identified on site were collected to be identified by comparison with herbarium samples from the National Floristic Center of Félix Houphouët-Boigny University.

\subsection{Data analyzes}

\subsubsection{Cartographic data analyzes}

Three major successive phases have made it possible to produce the maps: the supervised or directed classification of satellite images, their validation and the characterization of the dynamic of land use.

\subsubsection{Supervised classification of images}

Classification corresponds to the action of extrapolating, over the entire satellite image, test areas previously chosen during field visits and whose thematic significance is known (Oszwald, 2005).

Two major stages characterize this phase. This is on the one hand the selection of training plots and on the other hand the application of the classification algorithm. The training plots were selected on the basis of the sites visited and described during the data collection campaigns. Thus, 18 plots representing all types of land use were used as training for this treatment.

For this study, the most suitable algorithm for vegetation is maximum likelihood (Brou, 2005; Oszwald, 2005; Diallo et al., 2011). It makes it possible to calculate the probability of a pixel to belong to a certain class and therefore to reduce the risks of error of misclassified pixels by making the best use of the membership probabilities (Oszwald, 2005).

\subsubsection{Validation of classifications}

The validation of treatments makes it possible to assess the overall performance level of the treatment. This, in order to restore as faithfully as possible the land use classes described in the field. This leads to the development and analysis of the matrix of confusion.

It comprises two stages: the choice of control plots and the calculation of the cartographic precision.

The control plots correspond to sites described during the field visit but which were not used during training. A correspondence was established between the training plots and the control plots to assess the accuracy of the classification between the land use classes. Once the supervised classification was validated, a median $3 \times 3$ filter was applied. This filter reduced intra-class heterogeneity to eliminate isolated pixels.

\subsubsection{Spatial analysis of land use}

In this study, it will be a question of carrying out a remote sensing analysis which will consist in determining the different types of land use for the date 2020 and subsequently evaluating the area of each land use.

\subsubsection{Floristic data analyzes \\ 2.3.2.1. Floristic richness}

Floristic richness is defined as the number of species recorded in a given territory (Aké-Assi, 1984). Its measure consists in counting all the species recorded in each habitat without taking into account their abundance. It was the same for the families and genera of the listed species. The nomenclature of plant species adopted is that of Hutchinson \& Dalziel (1972), revised by Lebrun and Stork (1991-1997) and updated by APG IV. The compilation of all these lists provided the number of species in each habitat (secondary forests, fallows, and bamboo groves).

\subsubsection{Floristic composition}

The analysis of the floristic composition consisted in noting for each identified species, the biological type, the phytogeographic affinity based on the work of Aké-Assi (2001; 2002) The biological type of a species is the whole anatomical and morphological features which characterize its vegetative apparatus and which distinguish its physiognomy and habitat (Sørensen, 1948; Hakizimana, 2012). Phytogeographic affinities were used to distribute species according to their geographic distribution area. Thus, the following have been distinguished: 
the Guineo-Congolese species (GC). These species are distributed in the Guinean-Congolese phytogeographic region, the species (GC-SZ) subservient to the Guinean-Congolese and SudanoZambezian transition phytogeographic regions. Species (SZ) whose distribution area is in the Sudano-Zambezian phytogeographic region and, exotic or introduced species (I).

\subsubsection{Diversity indices}

\subsection{Shannon diversity index ( $\left.\mathrm{H}^{\prime}\right)$}

The Shannon Index $\left(\mathrm{H}^{\prime}\right)$ measures the species composition of a stand, taking into account species richness and relative abundance.

It has a value normally between 0 and 5 according to Magurran (2004), when it is calculated with the Natural logarithm (ln).

If we denote by $\mathrm{N}$ the total number of $\mathrm{S}$ species considered, nor the number of individuals of a species $\mathrm{i}$ and $\ln (\mathrm{ni} / \mathrm{N})$ the relative abundance of species i. It is calculated using the following formula:

$$
\mathrm{H}^{\prime}=-\sum[(\mathrm{ni} / \mathrm{N}) \mathrm{x} \ln (\mathrm{ni} / \mathrm{N})]
$$

This index varies from 0 (only one species present) to ln (S) (all the species present have the same abundance, therefore good diversity).

This index varies from 0 (only one species present) to ln (S) (all the species present have the same abundance, therefore good diversity).

\subsection{Piélou index (1966)}

For a stand, Pielou index tells us about the distribution of numbers among the different species. The calculation of the specific diversity index is always accompanied by that of equity, because two stands with different physiognomy can have the same diversity (Kouadio, 2006). Piélou's (1966) equity index (E), also called the equal distribution index (Blondel, 1979) is the ratio of the sample's Shannon index to maximum diversity. Pielou index varies from 0 to 1 . It tends towards 0 when almost all the numbers are concentrated in one species and towards 1 when all species have the same abundance. If this index tends towards 1 , the medium in question is said to be balanced. This index allowed us to highlight the level of balance of the different biotopes of the site. It is calculated using the following mathematical formula:

$$
\mathbf{E}=\mathbf{H}^{\prime} \quad / \ln \mathrm{S}
$$

In this formula, $\mathrm{E}$ denotes the Pielou index, $\mathrm{H}$ 'is the Shannon index and $\mathrm{S}$ represents the total number of species in the plot or area concerned.

\subsection{Margalef diversity index}

The diversity index proposed by Margalef (1957) is the quantity where $\mathrm{n} 1, \mathrm{n} 2$, ns are the numbers of species encountered in the sample, and $\mathrm{N}=\mathrm{n} 1+\mathrm{n} 2+$ ns. It represents the average amount of information (measured in bits) provided by the determination of an individual belonging to one of the $\mathrm{S}$ species. It is zero in the case of a single species $(\mathrm{n} 1=\mathrm{N})$, maximum and substantially equal to $\log _{2} \mathrm{~S}$ when the $\mathrm{S}$ species are also represented. Its mathematical expression is as follows:

$$
\mathbf{R}_{\mathbf{m g}}=\mathbf{S} / \mathbf{V N}
$$

With $\mathrm{S}$ number of species and $\mathrm{N}$ number of individuals. It was calculated because it corrects error bias because our different sites are not the same size.

\subsubsection{Venn diagram}

Venn diagram also called logic diagram, allows to represent sets and their intersections. As part of our study we used the Venn diagram to graphically represent the number of species common to land uses. The intercept between two circles is the number of common species between two land uses (Venn, 1880).

\section{Results}

\subsection{Land uses in the Dahliafleur Reserve}

The 2020 land use map made it possible to have the areas of the different types of land use and much more to know the exact location of each type of land use on the site.

The land uses identified by the mapping are: secondary forests, fallows and bamboo plantations (Figure 2). The overall precision and the Kappa coefficient are respectively $90.44 \%$ and $89.64 \%$. There is some confusion between certain classes. The highest are found between the fallow class and the forest and bamboo grove classes. These confusions are respectively 15.11 and 15.52 (Table 1). 


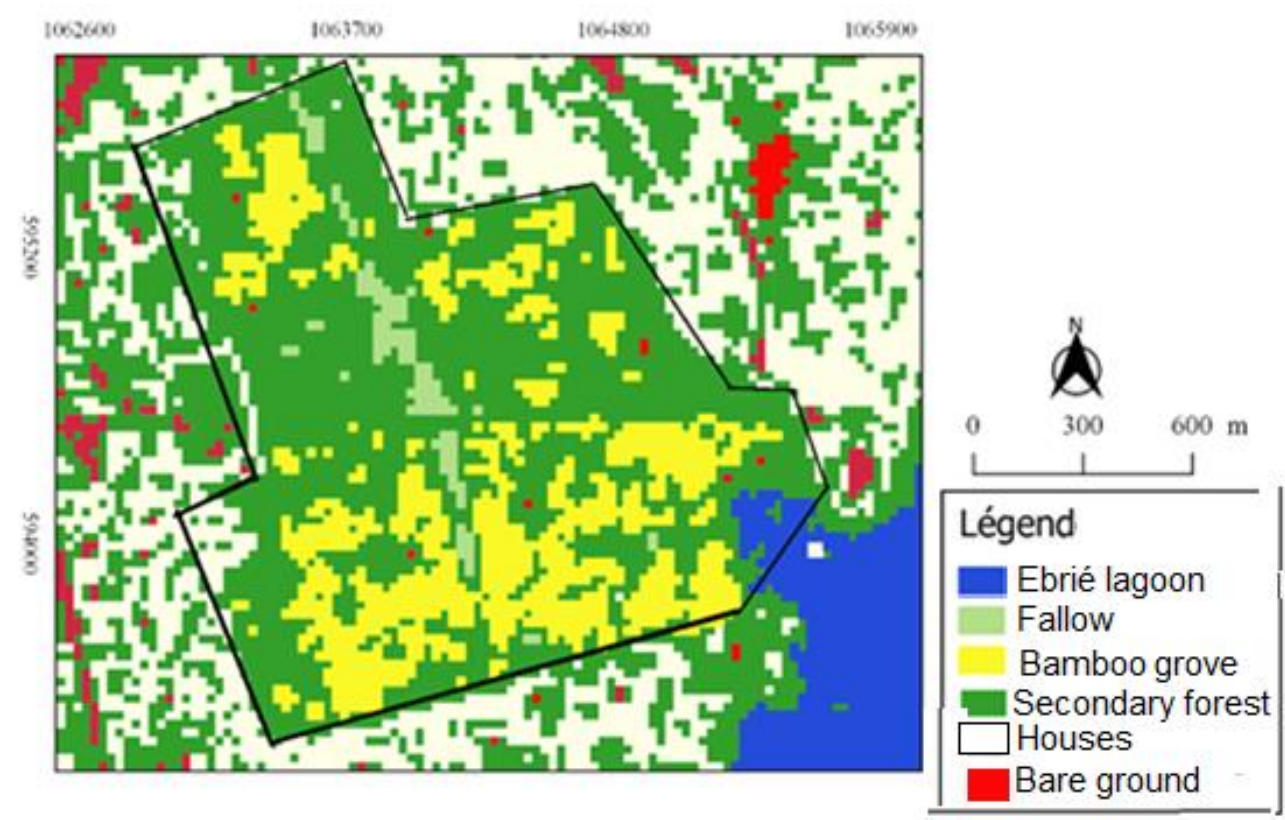

Figure 2: Maps of different land uses in Dahliafleur Reserve

Table 1: Confusion matrix of the 2020 mapping

Overall accuracy $=90.44 \%$

Kappa coefficient $=89.64$

\begin{tabular}{lccccc} 
Classes & Houses/Bare ground & $\begin{array}{c}\text { Secondary } \\
\text { forest }\end{array}$ & Bamboo grove & Fallow & Water \\
Houses/Bare ground & 97,08 & 0 & 0 & 1,94 & 6,69 \\
Secondary forest & 0 & 79,01 & 8,21 & 0,78 & 0,23 \\
Bamboo grove & 0 & 5,88 & 72,54 & 1,16 & 0 \\
Fallow & 2,92 & $\mathbf{1 5 , 1 1}$ & $\mathbf{1 5 , 5 2}$ & 96,12 & 0,35 \\
Water & 0 & 0 & 3,73 & 0 & 92,73 \\
Total & 100 & 100 & 100 & 100 & 100 \\
\hline
\end{tabular}

\subsubsection{Secondary forests}

Secondary forests are regrowth of vegetation. In other words, these are forests destroyed by human activities or not and which are recovering. The most common species are: Rauvolfia vomitoria Afzel, Sterculia tragacantha Lindl, Scottellia klaineana Pierre var. klaineana. There is a woody vegetation with 3 strata. These are the lower stratum ( 2 to $8 \mathrm{~m}$ in height), the middle stratum ( 8 to $16 \mathrm{~m}$ in height) and the upper stratum (16 $\mathrm{m}$ and more in height). Secondary forests cover practically the entire Reserve with an area of 90.89 ha (Table 2).

\subsubsection{Fallows}

Fallow land is an environment abandoned after cultivation. These are old plots of crops cultivated in the area. They vary with age. Their configuration and diversity can be assimilated to those of natural formations depending on the stage of reconstitution. They have an area of 19.13 ha, and are mostly located in the center of the Reserve. There are species such as Piptadeniastrum africanum, Strombosia pustulata, Dracaena arborea.

\subsubsection{Bamboo groves}

Bamboo groves constitute a monospecific plant formation, made up of a stratum made up of bamboo stubble and whose undergrowth is practically empty given the very high cover. They cover an area of 44.65 ha and are found more on the west and south side of the Reserve.

Table 2: Area of the different land uses in Dahliafleur Reserve

\begin{tabular}{ll}
\hline Land use & Area (ha) \\
\hline Secondary forest & 90.89 \\
\hline Fallow & 19.13 \\
\hline Bamboo grove & 44.65 \\
\hline Water & 4.78 \\
\hline
\end{tabular}




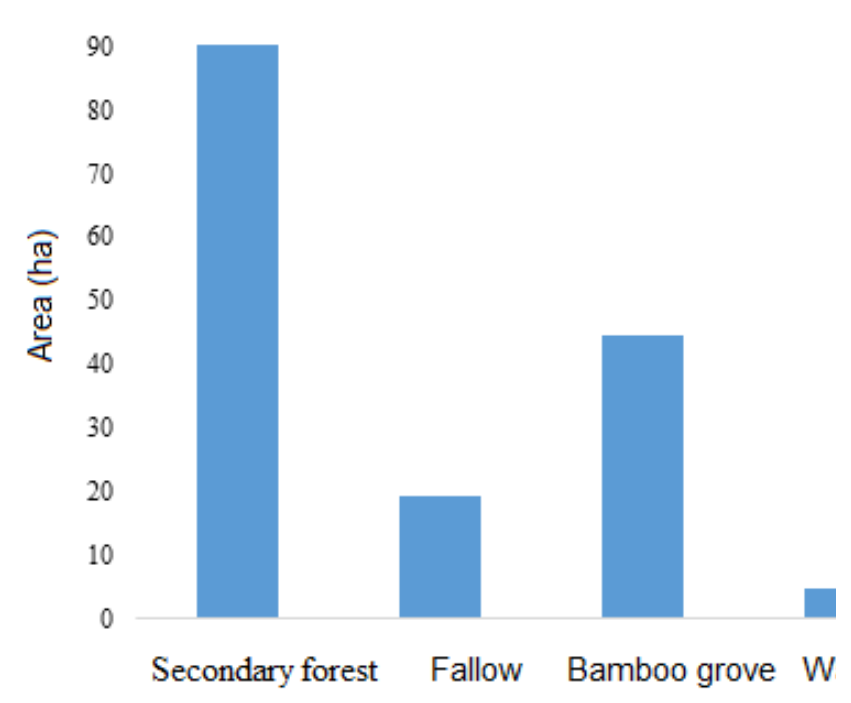

Figure 4: Histograms of the areas of the different land uses in the Dahliafleur Reserve

\subsection{Diversity of land uses in the study area 3.2.1. Specific richness}

The flora of the Dahliafleur Reserve includes 107 species, divided into 87 genera and 44 families. The Fabaceae family is the most diverse with 17 species, ie a rate of $16 \%$. It is followed by the Apocynaceae with nine (09) species ie $8 \%$, the Moraceae with seven (07) species ie a rate of $7 \%$ and Euphorbiaceae with the seven (07) species ie a rate of $6 \%$. Certain families like those of Anacardiaceae, Arecaceae, Asclepiadaceae, Asteraceae, etc., are represented by a single species. These monospecific families represent $50 \%$ of the flora.

Secondary forests include 68 species, 54 genera and 35 families (Table 3). That of fallows includes 64 species, 59 genera and 29 families. On the other hand, in bamboo groves, there is only one (01) single species, one (01) single genus and one (01) single family. It is Bambusa vulgaris. The families most represented in secondary forests and fallows are Fabaceae, Apocynaceae, Moraceae and Euphorbiaceae with different proportions (Figures 5 and 6).

Table 1: Floristic richness of Dahliafleur Reserve by land uses

\begin{tabular}{lcccc}
\hline Land use & Number of species & Number of genera & Number of families & $\begin{array}{l}\text { Average specific } \\
\text { richness }\end{array}$ \\
\hline Secondary forest & 68 & 54 & 35 & $17.50 \pm 5.47^{\mathrm{b}}$ \\
\hline Fallow & 64 & 59 & 29 & $17.17 \pm 5.67^{\mathrm{b}}$ \\
\hline Bamboo grove & 1 & 1 & 1 & $1.0 \pm 0.0^{\mathrm{a}}$ \\
\hline Total Dahliafleur & 107 & 87 & 44 & $\chi^{2}=11.85 ; p$-value $<0.05$ \\
\hline
\end{tabular}

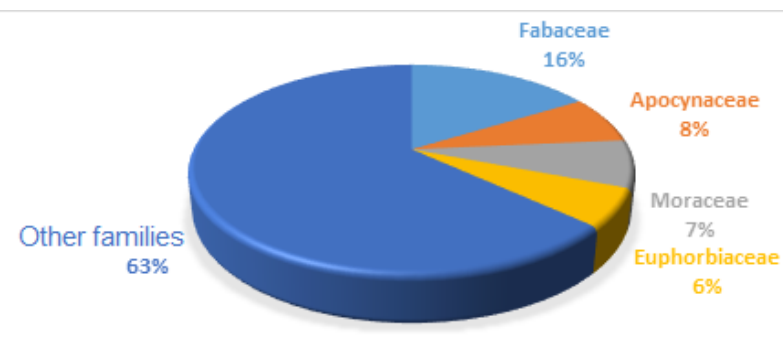

Figure 5: Spectrum of dominant families in the secondary forests of the Dahliafleur Reserve.

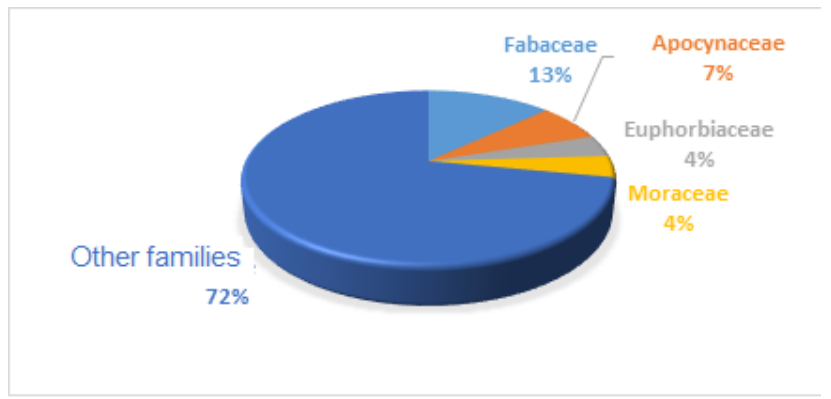

Figure 6: Spectrum of dominant families in the fallows of the Dahliafleur Reserve

\subsubsection{Floristic composition \\ 3.2.2.1. Biological types}

The biological spectrum of the species inventoried over the entire study site shows a clear dominance of phanerophytes with 96 species (Figure 7). Therophytes follow with four (04) species. Geophytes and chaméphytes have three (03) species each and hemicryptophytes have one (01) species. But it is the microphanerophytes which dominate with 55 species followed by the mesophanerophytes (24 species), the megaphanerophytes (10 species) and the nanophanerophytes (7 species). 


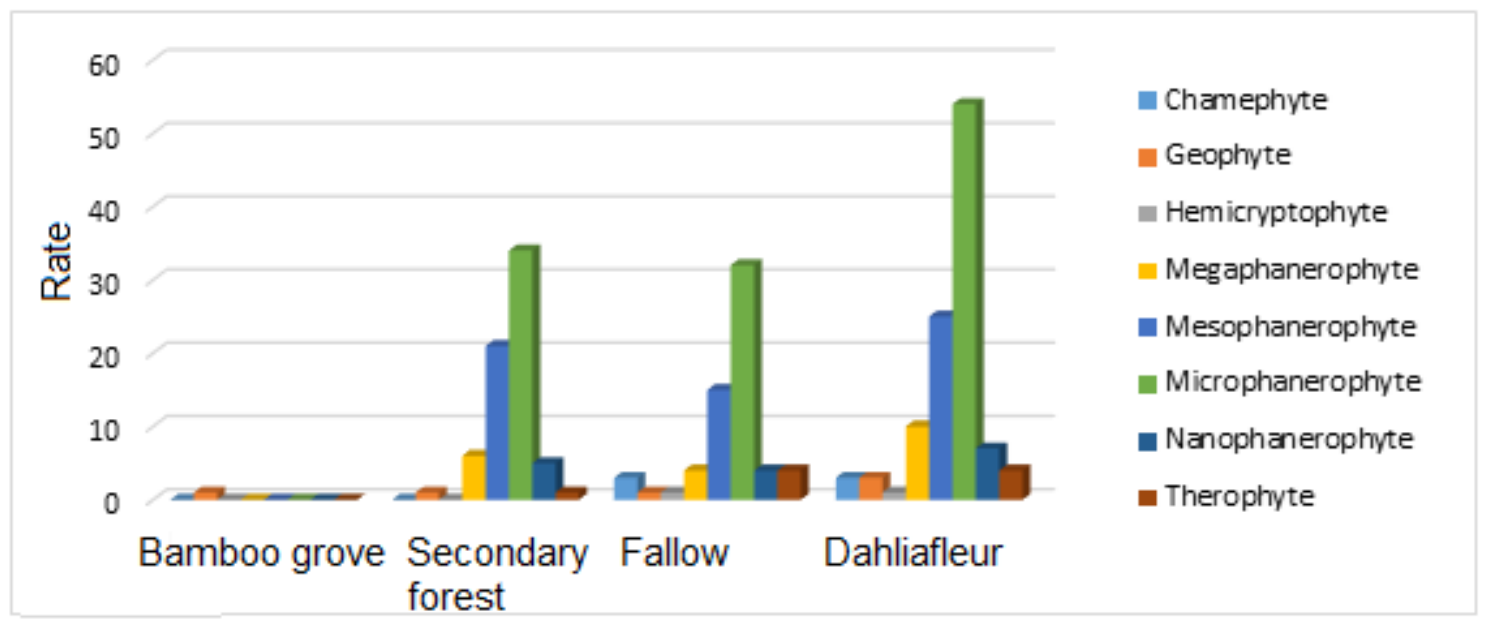

Figure 7: Histogram of the distribution of biological types by land uses

\subsubsection{Phytogeographical types}

All the species inventoried on the study site belong to five (05) phytogeographic types. Within the various land uses a tendency emerges. The Dahliafleur Reserve, through land uses such as secondary forests and fallow land, presents the same order of dominance of phytogeographical types. The GC species are those which dominate the flora of the Dahliafleur Reserve and those of the various land uses (figure 8).

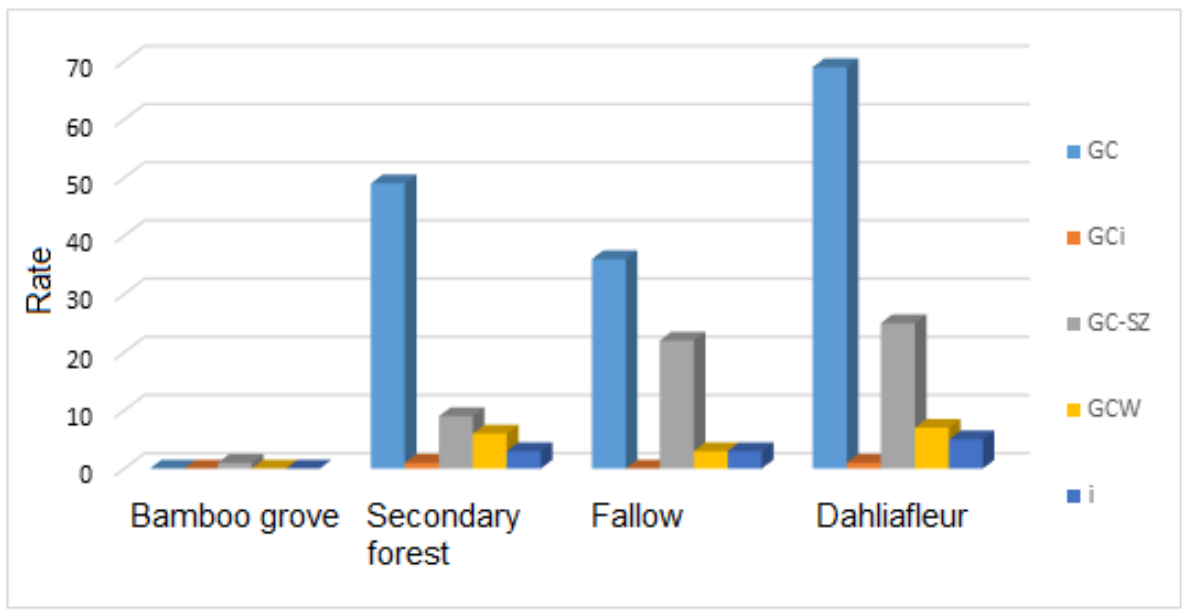

Figure 8: Histogram of the distribution of phytogeographic types by land use

GC: Taxon of the Guineo-Congolese region; GCW: Taxon endemic to the forest block in western Togo; GCi: Taxon endemic to Côte d'Ivoire; SZ: SudanoZambesian region taxon; GC-SZ: Taxon of the Guinea-Congolese and Sudano-Zambesian transition zone; i: introduced.

\subsubsection{Conservation value of the biodiversity of the} Reserve

The comparison of the species listed with those of Aké Assi (1998) and IUCN (2019), allowed us to identify three (03) species which appear on the IUCN red list which are Milicia regia (vulnerable), Placodiscus attenuatus, Placodiscus pseudostipularis both endangered (Table IV), two (2) species appear on the Aké-Assi list, these are Lannea nigritana and Milicia excelsa (Table 4). Among the species recorded in the Reserve, seven (07) are endemic to West Africa (GCW), one (01) is endemic to Côte d'Ivoire (Gci). These are Leptoderris miegei (Table 4). Six (6) species are endemic to Upper Guinea. These are Baissea zygodioides, Myrianthus libericus, Landolphia membranacea, Placodiscus attenuatus, Placodiscus pseudostipularis, Anthocleista nobilis. In terms of land uses, secondary forests constitute the most diverse land uses in species with special status, they are followed by fallows. Bamboo grove, on the other hand, have no species of conservation value (Table 4). 
Table 2 : List of species with special status recorded in the Dahliafleur Reserve

\begin{tabular}{lllll}
\hline & Species & Land uses & Endemism & IUCN 2019 \\
\hline 1 & Afzelia bella & Secondary forest & GCW & $\mathbf{1 9 9 8}$ \\
2 & Anthocleista nobilis & Fallow & GCW-HG & HG \\
3 & Baissea zygodioides & Fallow & Fallow - Secondary forest & GCW \\
4 & Dracaena cristula & Secondary forest & GCW-HG & PRE \\
5 & Landolphia membranacea & Fallow & Gci & PRE \\
6 & Lannea nigritana & Secondary forest & \\
7 & Leptoderris miegei & Secondary forest & & \\
8 & Milicia excelsa & Secondary forest & GCW & Endangered \\
9 & Milicia regia & Fallow - Secondary forest & HG & Endangered \\
10 & Myrianthus libericus & Secondary forest & GCW-HG & \\
11 & Placodiscus attenuatus & Fallow - Secondary forest & GCW-HG & \\
\hline
\end{tabular}

Table 3 : Distribution of species with special status in the different land uses

\begin{tabular}{lcccccc}
\hline \multirow{2}{*}{ Land uses } & \multicolumn{2}{c}{ Endemic species } & \multicolumn{2}{c}{ IUCN (2019) } & \multicolumn{2}{c}{ Aké Assi (1998) } \\
\cline { 2 - 7 } & Gci & GCW & HG & Endangered & Vulnerable & 0 \\
Bamboo grove & 0 & 0 & 0 & 0 & 1 & 0 \\
Secondary forest & 1 & 6 & 6 & 2 & 0 & 2 \\
Fallow & 0 & 3 & 4 & 1 & 1 \\
\hline
\end{tabular}

\subsubsection{Floristic diversity indices}

\subsubsection{Intra-specific diversity indices}

Considering the different types land uses, the value of the Shannon index varied from one land use to another. The largest mean value of the Shannon index $(2.45 \pm 0.24$ bits) was observed in the fallow (Table 6). The lowest value was recorded in the bamboo grove with an average index of $0.0 \pm 0.0$ bit. Its values reflect a good diversity of species in fallow, unlike the zero value in the bamboo grove which quite simply means the existence of a single species in this land use. The average values are not statistically different.

The Pielou index values vary from 0.88 bit to 0.0 respectively for fallow and bamboo grove.
The value of the Pielou index for fallow and secondary forest tends towards 1 , which reflects an equipartition of individuals within the different land uses. The zero value in bamboo grove translates into the dominance of a single species in this land use which is Bambusa vulgaris. The average values are not statistically different.

Margalef index values vary from $2.47 \pm 0.56$ bits to $0.12 \pm 0.03$ bits respectively for secondary forest and bamboo grove. These values show a good diversity of species in secondary forest and fallow. The average values are not statistically different.

Table 6. Specific diversity in the different land uses

\begin{tabular}{lccc}
\hline & Shannon index & Pielou index & Margalef index \\
\hline Secondary forest & $2.43 \pm 0.45^{\mathrm{b}}$ & $0.86 \pm 0.1^{\mathrm{a}}$ & $2.47 \pm 0.56^{\mathrm{b}}$ \\
\hline Fallow & $2.45 \pm 0.24^{\mathrm{b}}$ & $0.88 \pm 0.07^{\mathrm{b}}$ & $2.36 \pm 0.4^{\mathrm{b}}$ \\
\hline Bamboo grove & $0.86 \pm 0.1^{\mathrm{a}}$ & $0 \pm 0^{\mathrm{a}}$ & $0.12 \pm 0.03^{\mathrm{a}}$ \\
\hline Statistic & $\chi^{2}=11.9 ; p$-value $<0.05$ & $\chi^{2}=11.84 ; p$-value $<0.05$ & $\chi^{2}=11.38 ; p$-value $<0.05$ \\
\hline
\end{tabular}

The means assigned the same letter are significantly equal to the threshold of 5 p.c.

\subsubsection{Floristic similarity between the different} land uses

The Venn diagram gives the balance of the subservient and common species of the different types of land use (Figure 9). In secondary forest, there are 68 specific species, including 26 species common to secondary forest and fallow, and 0 species present in secondary forest and bamboo grove. In the fallow, the specific species are in numbers of 38 species. There are 26 species common for fallow and secondary forest, as well as 0 species common to fallow and bamboo grove. And in the bamboo grove, there is only one specific species and 0 species in common with the other two land uses.
We note especially in the figure, 0 species common to the three land uses.

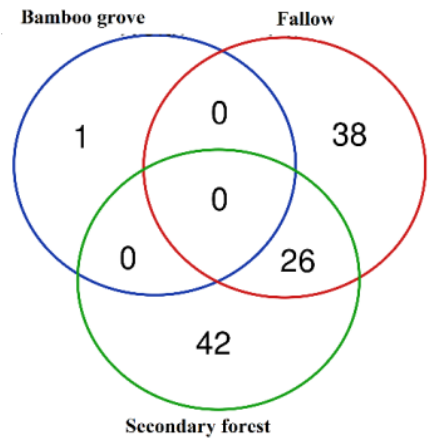

Figure 9: Venn diagram showing the degree of similarity between land uses in the Dahliafleur Reserve. 


\section{Discussion}

The value of the Kappa coefficient is 89.64. The classifications are therefore considered acceptable because the values of the Kappa coefficient are greater than 75 p.c (Girard and Girard, 1999). Because of this, there is a substantial agreement between the cards and the truth on the ground. The values of this coefficient are close to those found by Gnagbo (2015) who worked in Azagny with the same types of images. Whereas N'Da (2007) and Sangne (2009) obtained values of the Kappa coefficient different from ours. This difference is due to the fact that these authors worked in areas belonging to the mesophilic sector of the Guinean domain. Following our study, it should be noted that certain confusions encountered are to be noted. Coming in the same view, Pontius (2000) meant that the results of an image analysis with a Kappa coefficient greater than $50 \%$ are good and usable. Therefore, there is a relationship between the maps designed and the ground truth. Several authors, as Kpangui (2010) who conducted his study in Kokumbo; Sangne et al. (2015) in Haut-Sassandra, emphasized that the use of remote sensing indices provide useful and potential information for the knowledge of the state of the vegetation cover of a territory. The spatial analysis of the land use using sentinel images, took place in two phases including the determination of the areas of the land use units and the exact location of each of the land uses the results of the cartographic analysis show that secondary forests have the largest area with 90.89 ha, then bamboo groves with 44.65 ha and finally fallow with 19.13 ha. These values can be explained by the fact that since the acquisition of the site it has not been systematically destroyed as a whole. And its good conservation allows it to reconstitute itself slowly and tend towards its original status. This could explain the dominance of secondary forests at this site. The low proportion of fallows may be due to the fact that the aggressions are not completely canceled. Thus, the new destruction of vegetation explains the presence of fallows.

The area (44.65 ha) of bamboo groves can be explained by the fact that they are very competitive species in tropical forests, so their intensive proliferation has extended to this spatial occupation of this site.

The present study revealed 107 species, divided into 87 genera and 44 families. Our results are comparable to those obtained by Asseh (2019). This author, during his work in the Dahliafleur Reserve, identified 106 species divided between 39 genera. The low diversity of the Reserve can also be explained by the homogeneity of the vegetation. Indeed, according to Mbaygone (2008), the greatest floristic diversity is linked to the diversity of habitats or environmental heterogeneity.

The Dahliafleur Reserve is dominated by botanical families such as Fabaceae, Apocynaceae, Euphorbiaceae, and Moraceae. Indeed, the majority of ivorian forests are dominated by the same families (Kouamé et al., 1998; Nusbaumer et al., 2005; N'Da et al., 2008).

Phanerophytes are most abundant in secondary forests and fallows. This dominance of phanerophytes does not depart from the high diversity of tree species often reported in tropical forests (Blanc et al., 2003). Our results are confirmed by Sokpon (1995) and Habiyaremye (1997) who also demonstrated the dominance of phanerophytes in their study areas. According to these authors, it is the rule that in the forest phanerophytes form almost the entire floristic procession and that the other biological types are poorly represented. The low representativeness of hemicryptophytes, geophytes and therophytes is not only the prerogative of the Dahliafleur Reserve. The low proportions of these biological types, mostly heliophilic species, can be explained by the dominance of phanerophytes which reduce their establishment (Bangirinama et al., 2010). The same observation was also made in evergreen forest by Devineau (1984).

Guineo-Congolese species are largely dominant in secondary forests and fallows. According to Sonké (1998), the high proportion of these species in the floral procession of a forest is proof that it does indeed belong to the Guineo-Congolese region of White (1983). According to White (1983), the Guinean-Congolese flora is very pure with more than 80 to 90 p.c of endemic species and only about 10 p.c of species of binding elements. The relatively large proportions of species in the GC-SZ transition zone are evidence that all site spaces still suffer from the persistent effects of degradation (Assié et al., 2008).

The non-negligible proportions of species with special status give the Dahliafleur Reserve a particular interest for conservation as suggested by Myers et al. (2000). According to these authors, conservation efforts for endemic species, rare species and endangered species must be a priority in this kind of space.

This richness in species with special status contrasts with the urban environment and could be the result of a more or less effective development and conservation policy entrusted to various State structures such as the OIPR for the Dahliafleur Reserve (Monssou, 2018)

The low values of the diversity indices could be explained by the lack of stability of the flora of the 
different types of land use of the Reserve. Because according to Loubier (2001), the more unstable a space, the less diversified it is. The Dahliafleur Reserve still continues to suffer from anthropogenic pressures despite its status.

The low floristic similarity between the different types of land use in the Dahliafleur Reserve is due to the fact that these areas do not present the same metological conditions. This suggests that the Dahliafleur Reserve presents floristic variability, diverse habitats and great variability in ecological conditions.

\section{Conclusion}

The objective of this study was to determine the ecological role of the Dahliafleur Reserve. It has shown that this Reserve presents a variability in land use.

The analysis of the flora made it possible to identify 107 species divided into 87 genera and 44 families. The most numerous families are Fabaceae, Apocynaceae, Euphorbiaceae and Moraceae. Microphanerophytes are dominant. Species from the Guineo-Congolese region also dominate the Reserve. The significant presence of species with special status confers a particular interest for the conservation of the Reserve. Unfortunately, this Reserve is still under enormous human pressure. Agricultural practices, severe constraints due to urbanization and sometimes the collection of medicinal plants by the riparian population and their regular penetration into the Reserve make it a very vulnerable forest mosaic.

\section{Conflict of interests}

The authors have not declared any conflict of interests.

\section{Acknowledgements}

The authors express profound gratitude to Ivorian Office of Parks and Reserves (OIPR) for for the easy access to the Reserve.

\section{References}

1. Adou Yao C.Y. (2007). Inventaire préliminaire de la flore et description de la végétation de la Forêt des Marais Tanoé. Rapport pour RASAP-CI, Abidjan, Côte d'Ivoire.: 29 p.

2. Aké-Assi L. (1984). La flore de la Côte d'Ivoire : étude descriptive et biogéographique, avec quelques notes ethnobotaniques. Tome I, II, III. Thèse Doctorat d'État ès Sc. Nat. FA.S.T., Université Nationale de Côte d'Ivoire, Abidjan, $1205 \mathrm{p}$.

3. Aké-Assi L. (2001). Flore de la Côte d'Ivoire 1, catalogue, systématique, biogéographie et écologie. Conservatoire et Jard. Bot., Genève, Switzerland, Boissiera 57, 396 p

4. Aké-Assi L. (2002). Flore de la Côte d'Ivoire 2, catalogue, systématique, biogéographie et écologie. Conservatoire et Jard. Bot., Genève, Switzerland, Boissiera 58, 401 p.

5. Asseh E.E. (2019). Etudes floristique, phytogéographique et ethnobotanique des Acanthaceae de Côte d'Ivoire : cas de la Réserve Naturelle Partielle de Dahliafleur, dans le district autonome d'Abidjan et essais de domestication de Justicia flava (FORSSK) vahl, pour l'horticulture. Thèse de
l'Université Félix Houphouët-Boigny, Spécialité Systématique, Ecologie et Biodiversité Végétale, 245 p.

6. Assié K. H., Angui K. T. P. et Tamia A. J. (2008). Effets de la mise en culture et des contraintes naturelles sur quelques propriétés physiques d'un sol ferralitique au centre ouest de la Côte d'Ivoire : conséquences sur la dégradation des sols. European Journal of Scientific Research, 23 (1): 149-166.

7. Bangirinama F., Bigendako M. J, Lejoly J., Noret N., De Cannière C. \& Bogaert J. (2010). Les indicateurs de la dynamique post-culturale de la végétation des jachères dans la partie savane de la réserve naturelle forestière de Kigwena (Burundi). Plant Ecology and Evolution 143 : 138-147.

8. Blanc L., Florès O., Molino J. F., Gourlet S.-Fleury et Sabatier D. (2003). Diversité spécifique et regroupement d'espèces arborescentes en forêt guyanaise. Revue Forestière Française. $L V .16$ p.

9. Blondel J., 1979. Biologie et Ecologie. Masson \& Cie, Paris (France), $173 \mathrm{p}$.

10. Brou Y. T. (2005). Climat, mutations socio-économiques et paysages en Côte d'Ivoire. Mémoire de synth. Université des Sciences et Technologies de Lille, France, 212 p.

11. Devineau J.-L. (1984). Structure et dynamique de quelques forêts tropophiles de l'Ouest africain (Côte d'Ivoire). Université Pierre et Marie Curie-Paris VI. (France), 294 p.

12. Diallo H., Barnba, I., Barima Y.S.S., Visser M., Ballo A. Marna A., Vranken I., Maïga M., et Bogaert J. (2011). Effets combinés du climat et des pressions anthropiques sur la dynamique évolutive de la végétation d'une zone protégée du Mali (Réserve de Fina, Boucle du baoulé). Sécheresse, 22 (3) : 97-107.

13. Edlin E., Avenard J.M., Girard G., Sircoulon J., Touchebeuf P., Guillaumet J.L., Adjanohoun E. \& Perraud A. (1971). Le milieu naturel de la Côte d'Ivoire. ORSTOM, Paris, France, p 73-108.

14. Elander I., Lundgren Alm E., Malbert B. and Sandstrôm U.G (2005). «Biodiversity in urban governance and planning. Examples from Swedish cities». Planning TheO/y and Practiee, vol. 6, no 3, p. 283-301.

15. Hakizimana P. (2012). Analyse de la composition, de la structure spatiale et des ressources végétales naturelles prélevées dans la forêt dense de Kigwena et dans la forêt claire de Rumonge au Burundi (Unpublished doctoral dissertation). Université libre de Bruxelles, Faculté des Sciences - Ecole Interfacultaire des Bioingénieurs, Bruxelles, $141 \mathrm{p}$.

16. Girard M. C. \& Girard C. M. (1999). Traitement des données de télédétection. Dunod, Paris, France, 529 p.

17. Gnagbo A. (2015). Diversité et distribution des épiphytes vasculaires dans les forêts côtières de Côte d'Ivoire : Cas du Parc National d'Azagny. Thèse Doctorat, UFR Biosciences, Université Félix Houphouët-Boigny, Abidjan, Côte d'Ivoire, 208 p.

18. Habiyaremye M. K. F. X. (1997). Étude phytosociologique de la dorsale orientale du lac Kivu. Musée Royal de l'Afrique Centrale, Tervuren, Belgique; Annales Sciences Economiques, 24, 276 p.

19. Hutchinson, J. \& Dalziel, J.M., 1954-1972. Flora of West Tropica Africa, 2 nd edition. Revised by Key R.W.J., Hepper, F.N. Crown Agent, London, 3 vol.

20. Kouadio H.B. (2006). Apport de la télédétection et d'un Système d'Information Géographique (SIG) a la gestion intégrée et participative des aires protégées en Côte d'Ivoire : application au parc national de Comoé (réserve de biosphère), Rapport d'étude, $66 \mathrm{p}$.

21. Kouamé N'. F. (1998). Influence de l'exploitation forestière sur la végétation et la flore de la forêt classée du Haut Sassandra (Centre-Ouest de la Côte d'Ivoire). Thèse Doctorat $3^{\text {ême }}$ Cycle, UFR Biosciences, Université Cocody-Abidjan. $227 \mathrm{pp}$.

22. Kouamé D., Adou Yao C. Y., Kouassi K. E., N'Guessan K. E. \& Akoi K. (2008). Preliminary floristic inventory and diversity in Azagny National Park (Côte d'Ivoire). European Journal of Scientific Research, 23 : 537 - 547.

23. Kouamé D. (2009). Rôle des animaux frugivores dans la 
régénération et la conservation des forêts : cas de l'éléphant (Loxodonta africana cyclotis) dans le Parc National d'Azagny (Sud-Ouest de la Côte d'Ivoire). Thèse de Doctorat, Université de Cocody-Abidjan, Côte d'Ivoire, 208 p.

24. Kouassi, K. E., 2000. Contribution à l'étude de la Flore de la Forêt Classée de la Haute Dodo, dans le Sud-Ouest de la Côte d'Ivoire, par une approche de relevé de surface. Mém. D.E.A. U.F.R. Biosciences, Université de Cocody, Abidjan, 102 p.

25. Kouassi, K. E. 2007 Flore de la Forêt Classée de la Haute Dodo, dans le Sud-Ouest de la Côte d'Ivoire. Etude de quelques espèces commercialisées : cas de Garcinia afzelii (Clusiaceae), des rotins (palmiers lianes) des genres Calamus, Eremospatha, et Laccosperma (Arecaceae). Mém. Thèse unique. UFR Biosciences, Université de Cocody, Abidjan, $214 \mathrm{p}$.

26. Kpangui K.B. (2010). Apport des Systèmes d'Informations Géographiques à l'étude de la diversité spécifique de l'arboretum du Centre National de Floristique (Côte d'Ivoire). Mémoire DEA, Université de Cocody -Abidjan, Côte d'Ivoire, $64 \mathrm{p}$.

27. Lebrun, J.-P., \& Stork, A. L., 1991. Énumération des plantes à fleurs d'Afrique tropicale: Généralités et Annonaceae à PandaceaeVol 1, Conservatoire et Jard. Bot., Genève, 249 p.

28. Lebrun, J.-P. \& Stork, A. L., 1997. Énumération des plantes à fleurs d'Afrique tropicale: Gamopétales : Ericaceae à Lamiaceae, Vol 4, Conservatoire et Jard. Bot., Genève, 712 p.

29. Loubier J-C. (2001). Ecologie et SIG : un outil de gestion patrimoniale appliqué aux espaces naturels touristiques. Vème rencontre de Théo Quant, $14 \mathrm{p}$.

30. Magurran A.E. (2004). Measursuring biological diversity. Blackwelll Publ. Company United Kingdom, New Jersey, US, $248 \mathrm{p}$.

31. Magarlef R. (1957). La teoria de la informacion en ecologia. Mem. Real Acad. Ciencias by Artes de Barcelona 32:373449.

32. Mbayngone E. (2008). Flore et végétation de la réserve partielle de la faune de Pama Sud-est du Burkina-Faso. Thèse Unique, Univ. Ouagadougou (Burkina Faso). 138p + Annexes.

33. Monssou O.E. (2018). Diversité végétale et place du jardin botanique de Bingerville et de la Réserve Naturelle Partielle de Dahliafleur dans la vie des populations du district d'Abidjan (Côte d'Ivoire). Thèse de l'Université Félix Houphouët-Boigny, Spécialité Systématique, Ecologie et Biodiversité Végétales, 191p.

34. Müller N. et Werner, P. (2010). « Urban biodiversity and the case for implementing theconvention on biological diversity in towns and cities », in Müller, N., P. Werner and J. G. Kelcey (Ed.), Urban Biodiversity and Design, John Wiley and Sons : Oxford, UK, chapter 1.

35. Myers N., Mittermeier R. A., Mittermeier C. G., Da Fonseca G. A. B. \& Kent J. (2000). Biodiversity hotspots for conservation priorities. Nature, $403: 853-858$.

36. N'Da D. H. (2007). Étude et suivi par télédétection et système d'information géographique d'une aire protégée soumise aux pressions. Thèse de Doctorat unique. Univ. Cocody-Abidjan, Côte d'Ivoire, $174 \mathrm{p}$.

37. N'Da D. H., Adou Y. C.Y., N'Guessan K. E., Koné M. \& Sangne Y. C. (2008). Analyse de la diversité floristique du parc national de la Marahoué, Centre-Ouest de la Côte d'Ivoire. Afrique Science 04 (3) : 552 - 579
38. Nusbaumer L., Gautier L., Châtelain C. \& Spichiger R. (2005). Structure et composition floristique de la forêt classée de Scio. Candollea, 60 (2) : 393-443.

39. Oszwald J. (2005). Dynamique des formations agroforestières en Côte d'Ivoire (des années 1980 aux années 2000). Université des Sciences et Technologies de Lille. UFR de Géographie et d'aménagement, Laboratoire de Géographie des Milieux Anthropisés (UMR CNRS 8141). Thèse de Doctorat de Géographie, France, 304 p.

40. Pickett S.T.A, Cadenasso M.L. (2006). «Advancing urban ecological studies: Frameworks, concepts, and results from Ihe Ballimore Ecosystem Study». Auslra/ Ecology, vol. 31, p. J 14-125.

41. Piélou E. C. (1966). The measurement of diversity in different types of biological collections. Journal of Theoretical Biology, 13: 131-144.

42. Pontius J.R. R. G., (2000). Quantification error versus location error in comparison of categorical maps Photogrammetric Engineering \& Remote Sensing, 66: pp 1011-1016.

43. Sangne Y. C. (2009). Dynamique du couvert forestier d'une aire protégée soumise aux pressions anthropiques : cas de la forêt classée de Téné dans le département d'Oumé (CentreOuest de la Côte d'Ivoire). Thèse de Doctorat, Université de Cocody-Abidjan, Côte d'Ivoire, $220 \mathrm{p}$.

44. Sangne, C. Y., Barima, Y. S. S., Bamba, I., et N'Doumé, C. T. A. (2015). Dynamique forestière post-conflits armés de la Forêt classée du Haut-Sassandra (Côte d'Ivoire), VertigO, 15(3): 1-18.

45. Sonké B. (1998). Études floristiques et structurales des forêts de la réserve de faune du Dja (Cameroun). Thèse de Doctorat, Université Libre Bruxelles, Belgique, 267 p.

46. Sørensen T. (1948). A method of establishing groups of equal amplitude in plant sociology based on similarity of species content, and its application to analysis of the vegetation on Danish commons. In GOUNOT, P. M. [ed.], Méthode d'étude quantitative de la végétation. Masson et Cie, Paris, pp. 1-34.

47. Sokpon N. (1995). Recherches écologiques sur la forêt dense semi-décidue de Pobe au Sud-Est du Bénin : groupements végétaux, structure, régénération naturelle et chute de la litière. Thèse de doctorat, Université Libre de Bruxelles, Belgique, $350 \mathrm{p}$.

48. Tchouto G. P. M. (2004). Plant diversity in Central African rain forest: implication for biodiversity conservation in Cameroon. PhD. Thesis, Departement of Plant Sciences, Biosystematic Group, Wageningen University, Pays-Bas, 208 p.

49. Venn J. (1880). On the diagrammatic and mechanical representation of propositions and reasonings. The London, Edinburg, and Dublin philosophical magazine and journal of science, 10(59): 1-18vieira D.L.M. Scenariot A., 2006.principle of natural regeneration of tropical dry forests restoration. Restoration Ecology 14 : 11-20.

50. Vroh B. T. A. (2013). Evaluation de la dynamique de la végétation dans les zones agricoles d'Azaguié (sud-est, Côte d'Ivoire). Thèse Doctorat, UFR Biosciences, Université Cocody- Abidjan, Côte d'Ivoire, $208 \mathrm{p}$.

51. White F. (1983). The Vegetation of Africa. A descriptive memoir to accompany the Unesco/AETFAT/UNSO map of Africa, Unesco, Paris, France, 384 p 